\title{
EXPERIMENTAL VERIFICATION OF AURICULODIAGNOSIS IN THE DOG
}

\author{
J. ŠTILL and J. KONRÁD
}

Department of Diagnosis, Therapy and Control of Animal Diseases, University of Veterinary Science, 61242 Brno

Received fune 7, 1984

\begin{abstract}
Štill J., J. Konrád: Experimental Verification of Auriculodiagnosis in the Dog. Acta Vet. Brno, 54, 1985: 169-175.

Literature data on human acupuncture, concerned with the so called auriculodiagnosis, have been verified by a clinical experiment. Five halthy dogs of the Beagle breed ( 2 males and 3 females) have been used for experiments. The experiments were based on the induction of a defined painful process on the body periphery strong paw compression by an elastic bandage - for 30 minutes. Electrical and algesic changes on the ear auricle have been evaluated prior to compression, during each compression and 10-15 minutes after the removal of compression - regularly in 5-10 minute intervals. Altogether we have carried out 10 experiments with the compression of the fore paw, 10 with the compression of the hind paw and 10 with the compression of both paws.

The following changes were observed: 1 . The skin impedance was lowered as compared with the measurement carried out prior to the experiment on the ear auricle area corresponding to the projection area of the fore or hind paw. This decrease was detected in $100 \%$ of cases on the ear homolateral with the paw, while only in $63.3 \%$ on the contralateral ear. During compression other specific areas with the lowered skin impedance sould have been found. 2. At the found points a repeated and pronounced painful reaction upon detection was observed, occurring more often on the auricle of the ear homolateral with the compressed paw as compared with the contralateral one. This painful reaction was manifested by a characteristic sudden jerk of head and body, a painful bark being sometimes noted.

The results suggest that there exists a relationship between the painful process on the paw and the electrical and algesic changes at a certain area of the auricle of the ear. This is also corroborated by the fact that the incidence of these changes was observed as early as five minutes following the paw compression.
\end{abstract}

Dog acupuncture, active ear points, diagnostic method, experimental verification.

Auriculodiagnosis and auriculotherapy - known as ear acupuncture - have recently been representing a newly formed branch of acupuncture making use of pressure-sensitive and electrically measurable points at the auricle of the ear for diagnostic and therapeutic purposes.

As early as in 1956, French physician P. Nogier first reported on the phenomenon of ear acupuncture. On the other hand, certain old Chinese acupuncture texts (e. g. from the T'ang dynasty in 618-907) describe a series of ear acupuncture points connecting them with the so called classical acupuncture points that are arranged into the pathe (meridian) system on the human body (Kropej 1977).

Ear acupuncture is included among the so-called microsystems such as e. g. the point system on the sole of the foot, that of nose and end parts of digits, i. e. concerning generally the acral parts of the body. During its short historical development the auriculoacupuncture has advanced considerably. Particularly in human acupuncture an extensive point system has been worked out, the diagnostic and therapeutic values of which have been verified many times, especially under clinical conditions (König 1975). Together with other acupuncture kinds the auriculoacupuncture 
is included among the reflex therapies; it is applied in the therapeutic control of mostly painful or other pathologic conditions in the organism.

The auriculodiagnosis is based on the fact that a disease of an organ (e., g. stomach) induces changes of reflex type at a certain part of the ear auricle. These changes are manifested in the following way:

1. Change in the impedance of skin - in most cases the skin impedance decrease appears, thus causing the increase of conductivity at the point when compared with the adjacent skin area. 2. Local painful reaction - in comparison with adjacent skin areas a markedly lowered threshold of pain induced by the contact with the detection electrode is usually observed. It is manifested by a violent jerk of the patient or by the so called "painful grimace".

3. Morphological changes of the point - particularly in chronic diseases morphological changes as reddening, desquamation, blisters etc. are usually described on corresponding ear points (Kropej 1977).

The quoted data can be found in literature dealing with human acupuncture and are based mostly on clinical experience. At present, the mapping of acupuncture points, corresponding to most body organs, body parts and some functions of the organism, is extensive and very detailed. The same acupuncture point can be used in both directions, both diagnostically and therapeutically.

In veterinary literature only very few contributions, mostly theoretical or casuistical, concerned with the ear acupuncture can be encountered. Krüger and Krüger (1980) have examined several dogs and cats after the experimental injury of articular cartilage and found painful points organized in a certain localization on their ear auricles. In dogs with clinical disturbances of the musculoskeletal system the puncturing of corresponding points at the ear auricle induced repeatedly remissions of the disease. Brunner (1979) has shown in dogs better therapeutical results of the body acupuncture when applied together with the ear acupuncture.

The aim of the present contribution is:

1. To carry out clinical experiments which would allow to evaluate changes at the dog ear auricle induced by the painful process on the periphery of the body.

2. To assess the role of sex, some external experimental conditions etc. upon the course and results of the experiment.

3. To consider if the results obtained correspond to the above mentioned criteria of auriculodiagnosis in human medicine and if the ear acupuncture can be considered as a more common biological phenomenon, applicable also in the field of veterinary acupuncture.

\section{Materials and Methods}

The experiment was carried out of five clinically healthy dogs of the Beagle breed ( 2 males and 3 females). Two restless animals were sedated seven times, three times with Chlorprothixem (Sedonal inj. Léčiva) and four times with Chlorpromazin (Chlorpromazine inj. Galenika).

For the detection of electrical and algesic changes on the dog ear auricle a Czechoslovak instrument Akudiast I with a nontraumatic spring-mounted detection electrode was used. The electrode detection area was $1 \mathrm{~mm}^{2}$, the detection pressure $784.8-11177.2 \mathrm{kPa}$ (i. e. $80-120 \mathrm{~g} \mathrm{~mm}^{-2}$ ).

The painful process on the body perifery was induced with a strong compression of a paw using an elastic bandage for 30 minutes. This compression was applied 30 times, out of which 10 times unilaterally the left or right fore paw was compressed, 10 times the hind paw and 10 times the compression of the fore and hind paws was combined. If a dog was used repeatedly in the experiment a break of at least 10 days was made in order to exclude a possible influence of the preceding experimental irritation. Prior to the onset of the experiment a clinical examination of an animal was carried out. Both externa auricles were carefully examined from the inner side, both visually and using the detection probe of the instrument. The electric and algesic changes on the external auricle and further possible reactions of the animal were evaluated both during the bandage compression and for the following $10-15$ minutes after bandage removal in 5-10 min intervals.

\section{Results}

\section{Changes in the impedance of skin}

A lowered skin impedance $(60-100 \mathrm{k} \Omega)$ has been observed 10 times in a series of skin points on both auricles (including points on the "hind" or "fore" paws found later), this representing $33 \%$. 
Table 1

Skin impedance in the projection point of the fore limb paw in dog

\begin{tabular}{|c|c|c|c|c|c|c|c|c|c|c|c|c|c|}
\hline Dog No. & 1 & 2 & 3 & 4 & 5 & 6 & 7 & 8 & 9 & 10 & Mean \\
\hline $\begin{array}{l}\text { Skin } \\
\text { impedance } k\end{array}$ & 30 & 30 & 40 & 35 & 40 & 35 & 50 & 40 & 40 & 20 & 36 \\
\hline
\end{tabular}

Table 2

Skin impedance in the projection point of the hind limb paw in dog

\begin{tabular}{|c|c|c|c|c|c|c|c|c|c|c|c|c|}
\hline Dog No. & 1 & 2 & 3 & 4 & 5 & 6 & 7 & 8 & 9 & 10 & Mean \\
\hline $\begin{array}{l}\text { Skin } \\
\text { impedance } \mathrm{k}\end{array}$ & 40 & 35 & 50 & 30 & 20 & 25 & 30 & 35 & 25 & 30 & 32 \\
\hline
\end{tabular}

Table 3

Skin impedance in the projection points of the fore and hind limb paws (simultaneous compression of both paws)

\begin{tabular}{|c|c|c|c|c|c|c|c|c|c|c|c|c|c|}
\hline Dog No. & 1 & 2 & 3 & 4 & 5 & 6 & 7 & 8 & 9 & 10 & Mean \\
\hline $\begin{array}{l}\text { Skin } \\
\text { impedance } k\end{array}$ & 20 & 30 & 50 & 30 & 35 & 20 & 25 & 25 & 35 & 30 & 30 \\
\hline
\end{tabular}

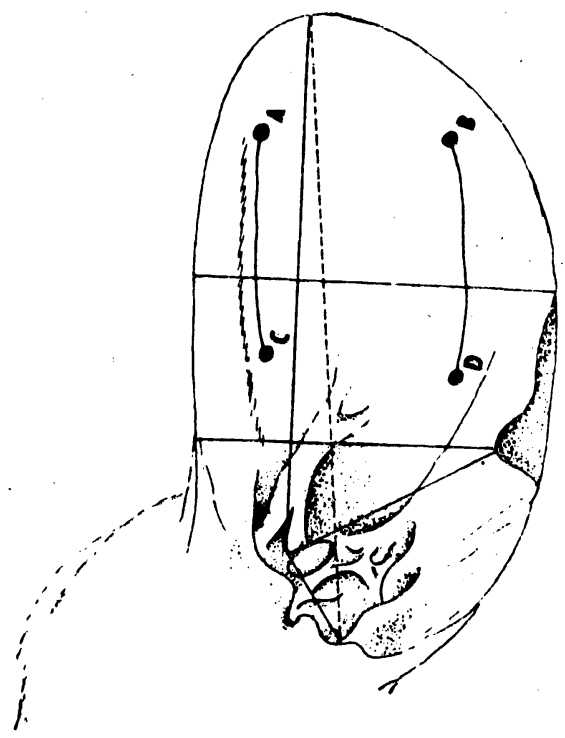

Fig. 1

Auriculodiagnostic finding in dogs. A-projection point of the hind limb paw, B - projection point of the fore limb paw, $C$ and $D$ - projection points of detection painfulness at the ends of lines of decreased skin impedance 
During the paw compression a pronounced decrease in skin impedance to $20-50 \mathrm{k} \Omega$ has occurred in all 30 measurements $(100 \%)$ at the corresponding projection points (A or B, depending on the projection point - See Fig. 1, Tables 1-3). When prolonging the time of compression the values were exhibiting a decreasing tendency and in 19 cases $(63.3 \%$ ) certain line patterns of the lowered skin impedance should be noted. These lines were directed towards the ear auricle base, roughly in parallel with its edge (Fig. 1). The decrease in skin impedance has been observed unilaterally with the compressed limb in $100 \%$ whereas in 19 cases $(63.3 \%)$ this decrease has been found on the contralateral auricle as well.

\section{Occurrence of painful points}

Following the paw compression the painful reaction appeared within five to ten minutes in 25 out of 30 cases $(84 \%)$ at the expected area of projection. If one limb was compressed (20 cases), the painful reaction was observed in $17(85 \%)$ and 13 $(65 \%)$ cases of the homolateral and contralateral ear, resp. (Fig. 2).

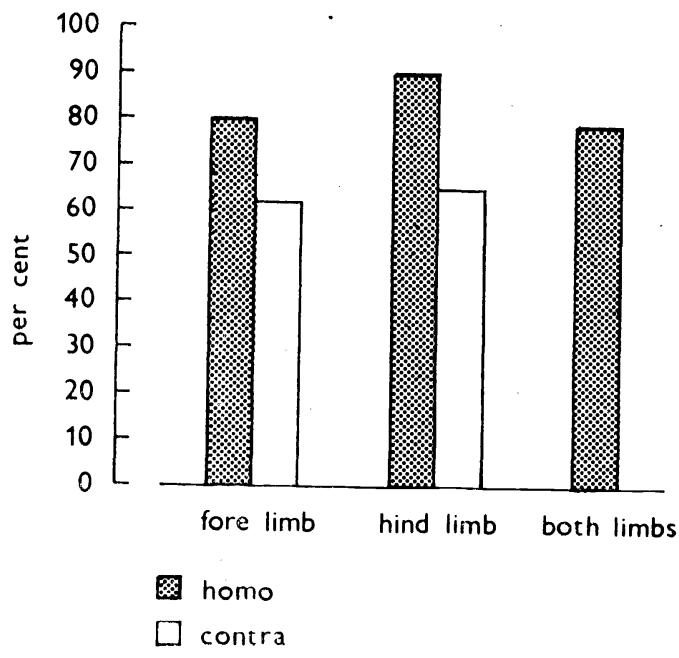

Fig. 2

Percentage of painful reactions on homolateral and contralateral auricles in dogs occurring after compression of the paw

The painful reaction was manifested by a sudden jerk of head and whole body, accompanied sometimes by a painful bark. Immediate reflex jerk of the compressed limb after the contact of detection electrode with the painful point has been observed seven times $(23.3 \%)$. During further examination yet another painful point at the end of the mentioned electrical line has been found (Fig. 1).

Visual changes on the ear auricle

No visual changes on the auricle skin have been observed during the experiment.

Influence of sedation on the experiment

In two restless animals mild somnolency was induced seven times using medication. In three cases $(42,9 \%$ ) no typical painful reaction appeared. 


\section{Discussion}

It is generally assumed (Vogralik and Vogralik 1978; Kropej 1977 and others) that manifestations of ear acupuncture are based on the nervous system activity. Innervation and blood perfusion of the dog ear auricle as compared with that of man has been studied by Noureau (1977). This author, on the basis of analogy of some anatomical structures, has transposed human ear points to the dog auricle. We believe, however, that a more correct way to active localization in the dog lies in experimental or clinical work.

In this work we have verified that in clinically healthy dogs, under physiological conditions, no painful points are located on the inner side of the auricle of the ear. Only in one third of animals individual points of a lowered skin impedance have been detected, however, not reaching the values typical for an active point $(60-70 \mathrm{k} \Omega$ as compared with $10-40 \mathrm{k} \Omega$, see Tables $1-3$ ). In these cases actual individual impedance values of the auricle surface (i. e. $60-70 \mathrm{k} \Omega$ ) were observed.

Following the paw compression, when direct pressure and later even ischemic pain was caused (Ganong 1976), a decrease in skin impedance appears in the active points of the ear auricle in all cases, which was in $84 \%$ of cases accompanied also by the occurrence of a typical painful reaction. From the experience obtained, it can be assumed that the painful reaction has to be evaluated individually, in comparison with the individual threshold of pain induced by pressure stimuli when the whole surface of ear auricle is being detected.

It may be concluded that, when using the statistical evaluation by the chi square method, the incidence of points exhibiting a lower skin impedance and an increased pressure-induced pain reaction is in a statistically significant relationship $(p<0.01)$ with the painful process on the paw.

Together with Logunov (1979) we believe that the values of skin impedance can objectively inform on functional condition of the autonomic system of the organism, their measurement being however often influenced by objective as well as subjective factors which can distort the results of measurement (Hálek, Kolářová and Opavský 1982). We have thus attemped to minimalize these negative effects by using a nontraumatic spring-mounted electrode.

Since no data have been available in the literature, concerning similar experiments in veterinary or human medicine, we are unable to compare our results with other authors. Kropej (1977) has observed the incidence of points with lowered skin impedance predominantly on the homolateral ear in humans whereas on the contralateral auricle with peripheral lesion this incidence reached only $10 \%$. In our study we have verified the lowering of the skin impedance in $100 \%$ on the homolateral and in $63.3 \%$ of cases also on the contralateral ear auricle. A similar tendency to a higher propagation towards the homolateral auricle of the ear can also be seen in the case of painful reaction Fig. 2. In no case morphologial changes on the ear auricle during the compression or after it (as known from human auriculodiagnosis in the case of chronic diseases - Kropej 1977) has been observed. It can be concluded from the measurements carried out after the experiment that painful points outstay at the same locality for several hours following the removal of compression.

It is possible that the manifestation of point painful reaction can be negatively influenced by drug-induced sedation. In five of our negative cases three animals were under the influence of a sedative.

Neither sex nor external experimental conditions were found to influence the experimental results. 


\section{Experimentální oyěření aurikulodiagnostiky u psů}

Formou klinického experimentu jsme ověřovali údaje $\mathrm{z}$ humánní akupunkturistické literatury, týkající se tak zvané aurikulodiagnostiky. $\mathrm{K}$ pokusu jsme použili pěti klinicky zdravých psů plemene beagle ( 2 psi, 3 feny). Vlastní pokus spočíval ve vyvolání definovaného bolestivého procesu na periferii těla - silné stažení tlapky pružným obinadlem na dobu 30 minut. Elektrické a algické změny na ušním boltci jsme hodnotili před kompresí i během komprese obinadlem a 10-15 minut po jeho odstranění - pravidelně v 5-10 minutových intervalech. Celkem jsme takto provedli 10 pokusů $\mathrm{s}$ kompresí přední tlapky, $10 \mathrm{~s}$ kompresí zadní tlapky a 10 pokusů $\mathrm{s}$ kompresí přední i zadní tlapky.

Zjistili jsme následující změny: 1. Došlo ke snížení kožního odporu vzhledem $\mathrm{k}$ stavu před pokusem $\mathrm{v}$ oblasti ušního boltce, která odpovídá projekčnimu místu přední, resp. zadní tlapky. Toto snižení jsme detekovali ve $100 \%$ případủ, během komprese se postupně dala zjistit $\mathrm{i}$ jiná specifická místa se sniženým kožním odporem.

2. V zmíněných bodech jsme v $84 \%$ př́padủ nalezli opakovaně výraznou bolestivost na detekci, častěji na ušním boltci homolaterálním $s$ komprimovanou tlapkou než na kontralaterálním. Tato bolestivá reakce se projevovala charakteristickým náhlým záškubem hlavy a těla, někdy i pes bolestivě vyštěkl.

Výsledky naznačuii souvislost mezi bolestivým procesem na tlapce a elektrickými a algickými změnami na určitém úseku ušního boltce. To podporuje i skutečnost, že k výskytu těchto změn docházelo již za pět minut po stažení tlapky.

\section{Экспериментальная проверка аурикулодиагностики у собак}

Формой клинического эксперимента проводили роверки данных, содержащихся в литературе по иглотерапии человека и касающихся так называемой аурикулодиатностики. Для экоперимента было использовано пять клинически здоровых собак племени бигль (двух псов и трех сук).

Собственны эксперимент заключался в том, чтобы вызвать определенное чувство боли на периферии тела интенсивным сжатием лапы гибким бинтом в течение 30 минут. Электрические и альгические изменения на ушной раковине оценивались в течение сжатия бинтом и 10-15 минут после его удаления в интервалах 5-10 минут. В общем проводили 30 экспериментов.

Были установлены следующие изменения: 1. понижение сопротивления кожи по отношению к состоянию перед экспериментом на ушной раковине, соответствующее месту на передней или задней лапе. Данное понижение был установлено во всех случаях, в ходе сжатия можно было постепенно определить также другие специфические места с пониженным сопротивлением кожи.

ным сопротивлением кожи. 2. В упомянутых точках в $84 \%$ случаев была повторно обнаружена резкая болезненность при ощупывании. Данная реакция проявлялась внезапным характерным дерганьем головы и тела, иногда болезненным воем. Упомянутая опецифическая реакция была чаще всего установлена на гомолатеральной ушной раковине со сжатой лапой. На других частях раковины данные изменения не были установлены.

Статистическая оценка свидетельствует о связи болезненного процесса на лапе и электрических, альгических изменений на определенном участ- 
ке ушной раковины, что подтверждается также тем обстоятельством, что данные изменения появлялись уже через пять минут после сжатия лапы.

Приведенные фракты свидетельствуют в соответствии с медициной человека о рефлекторной основе данных изменений.

\section{- References}

BRUNNER, F.: Die Bchandlung schmerzhafter Wirbclsäulenerkrankungen mit Akupunktur und Aurikulotherapie. Der Praktische Tierarzt, 60, 1979: 1 100-1 103

GANONG, W. F.: Přehled lékařské fyziologie (orig.: Review of medical physiology. Lange Medical Publications, Los Altos, 1973). Avicenum, Praha, 1976, pp. 105-106.

HÁLEK, J. - KOLÁR̆OVÁ, J. - OPAVSKÝ, J.: Problematika měřni odporu v aktivních bodech kủže. Fysiatrický věstník, 60, 1982: 258-266.

KÖNIG, G.: Theoretische Grundlage der Ohrakupunktur. Akupunktur - Theorie und Praxis, 3, 1975: $180-184$.

KROPEJ, H.: Systematik der Ohrakupunktur. Karl F. Haug, 3. Aufl., Heidelberg, 1977, pp. $19-16$. KRÜGER, H. - KRÚGER, P.: Ohrakupunktur bei Bewegungsstörungen der Kleintiere. Der Praktische Tierarzt, 61, 1980: 119-129.

LOGUNOV, C. P.: Impedanc koži - objektivnij kritěrij funkcionalnogo sostojanija vegetativnych otdělov něrvnoj systěmy. Věstnik děrmatologii $i$ veněrologii, 7,1979 : $21-25$.

NOUREAU, J. P. R.: Introduction de l'acupuncture auriculaire canine. École nationale de Toulouse, No 131, 1977: pp. 21-45.

VOGRALIK, V. G. - VOGRALIK, M. V.: Iglorefleksotěrapija. Volgo-Vjatskoje izdatělstvo, Gorkij, 1978, pp. $246-273$. 